\title{
Nigerian-Initiated Pentecostal/Charismatic Churches in the Czech Republic
}

\author{
Active Missionary Force or a Cultural Ghetto?
}

\author{
Pavol Bargár
}

Today, Pentecostal/charismatic forms of Christianity have come to represent the second largest community of Christians worldwide, after the Roman Catholic Church (Working Group on Mission and Ecclesiology 2012: 110). Within this Christian tradition, Nigerian and Nigerian-initiated Pentecostal/ charismatic churches have received much scholarly attention especially with respect to the context of (Western) Europe, not least due to the strong presence of Nigerian immigrants, including Nigerian Pentecostal/charismatic Christians, in many countries of the region (Asamoah-Gyadu 2006: 73-75; Asamoah-Gyadu 2005: 301-302; Währisch-Oblau 2009: 36-39). ${ }^{1}$ The phenomenon of the Nigerian Pentecostal/charismatic missionaries and communities led by them has been fairly well documented with respect to some Western European countries (Adeboye 2007; Hunt 2000; Olupona 2003; Wilkinson 1986; www.glopent.net). Moreover, this phenomenon has also been explored in Eastern Europe, particularly with regard to Sunday Adelaja's Church of the Embassy of the Blessed Kingdom of God for all Nations in Ukraine (Adogame 2008; Asamoah-Gyadu 2005; Asamoah-Gyadu 2006; Asamoah-Gyadu 2012). However, much less attention has been given to the presence and ministry of Nigerian-initiated Pentecostal/charismatic churches in Central Europe. The present chapter will seek to fill this lacuna by exploring the ministry of three Nigerian-initiated Pentecostal/charismatic churches in the city of Prague, the Czech Republic. These are 'The Mountain of Fire \& Miracles Ministries',

1 In the scholarly discourse it has proven as helpful to distinguish between 'Nigerian' and 'Nigerian-initiated' churches. While acknowledging this distinction, due to the extent and focus of this chapter we cannot elaborate further on this distinction. While the author of the present paper acknowledges the differences between the terms 'Pentecostal' and 'charismatic', for the purposes of the chapter it is not necessary to distinguish and elaborate them in detail. Therefore, the form 'Pentecostal/charismatic' will be used consistently throughout the chapter. For a detailed discussion see the bibliography.

Originally published in Exchange 43 (2014) 48-67.

(C) PAVOL BARGÁR, 2016 | DOI 10.1163/9789004326156_006

This is an open access chapter distributed under the terms of the CC-BY-NC License. 
'Covenant Parish Prague' of 'The Redeemed Christian Church of God', and 'The Holy Ghost End Time Ministries Intl.' respectively. The present article will analyze different strategies the three case-study churches use to move beyond their ethnic origin. Special attention will be paid to the role of indigenous elements (the context of the present-day Czech Republic) in the mission of these churches. On these particular case studies, the paper will test a thesis, suggested by the research done by various scholars with respect to the Nigerian Pentecostal immigration in Europe and, especially, Great Britain, which claims that Nigerian-initiated Pentecostal/charismatic churches in Europe fail to appeal to the population of non-Nigerian and non-Pentecostal/charismatic backgrounds. This contribution will suggest taking a more complex approach to the phenomenon by considering aspects such as contextual knowledge/ experience of the pastor, language politics, worldview, worship style, and outreach policy. It will demonstrate how the three case-study churches represent three various models for and expressions of Nigerian-initiated and -led Pentecostal/charismatic ministry in the local (Czech) context. It will be suggested that sheer numbers and demographics are not to be perceived as the main or even sole indicator of whether or not a specific church represents an active missionary force, but rather a multiplicity of factors should be taken into consideration.

The material for this writing was gathered during fieldwork conducted in the period of March to July 2012 and August 2013. The fieldwork was ethnographic in approach. The field research was conducted in the form of semi-structured interviews with the religious leadership of the case-study churches and supplemented with participant observation during worship services as well as informal interviews with church members. ${ }^{2}$ In addition, the websites and other materials (booklets, worship service leaflets, flyers, etc.) were analyzed.

2

Nigerian Pentecostal/Charismatic Christianity in Migration Contexts: A Way to Build a Cultural Ghetto?

While recent scholarship has studied various aspects of the phenomenon of Nigerian-initiated Pentecostal/charismatic churches, the focus of this chapter is to explore whether Nigerian-initiated Pentecostal/charismatic churches in the Czech Republic represent a dynamic and active missionary force which

2 I am very grateful to all the interviewees as well as the other people who helped me accomplish this research. 
addresses and receives response from the local society, or whether they represent a closed space that seeks first and foremost to foster a particular Nigerian identity.

In a recent article, Kwabena Asamoah-Gyadu argues against those who interpret the mission of African migrant churches 'one-sidedly in terms of survival strategies within hostile diaspora environments' and suggests taking into account 'very powerful, aggressive and strong evangelical witnessing strategies' which the African Christians adopt 'with the intention of re-making Europe and Europeans in the image of Christ' (Asamoah-Gyadu 2012: 26). Even if one acknowledges this clear missionary intention, however, the question remains, to what extent are these churches able to reach majority (non-African immigrant) population?

Kwabena Asamoah-Gyadu seems to be aware of this issue when he observes that the Church of the Embassy of the Blessed Kingdom of God for All Nations (or, shortly, God Embassy), founded by the Nigerian pastor Sunday Adelaja in Kyiv, Ukraine, is very different from other African-initiated Pentecostal/ charismatic churches in the diaspora in that it is 'not predominantly African in membership', thus inferring that the majority of African-Initiated Pentecostal/ charismatic churches have a predominant non-white/African membership (Asamoah-Gyadu 2006: 73).

Researching the mission of African-initiated Pentecostal/charismatic churches in Europe in general and that of the Redeemed Christian Church of God (RCCG) in Britain in particular, Steve Hunt argues that these churches 'have largely failed to win over white converts' in their quest to evangelize the 'dark continent of Europe' (Hunt 2002: 16). Rather, Hunt goes on to suggest, 'They provide the focus of identity and the source of inspiration for primarily Nigerian immigrants' (Hunt 2002: 16).

Based on his research on the ministry of Nigerian Pentecostal/charismatic churches (predominantly) in south-east London, Geoffrey Walker of Roehampton University says that there is little evidence that Nigerian Pentecostalism attracts non-religious Africans, the white British population or even black majority church Christians of earlier waves of immigration. Moreover, trying to find an answer to the question whether Nigerian Pentecostalism translates into local contexts of the West, Walker asserts that its 'theological dissonance creates a sense of religio-cultural ghetto that operates within a self-defining and legitimating hermeneutic' (Walker 2011).

The remainder of this chapter will test the aforementioned thesis for the case of Nigerian-initiated churches in Prague. However, before doing this, it briefly introduces some relevant features of the peculiar Czech context. 


\subsection{Religious Scene}

The Czech Republic has been notoriously known as one of the 'most atheistic countries in the world'. However, an increasing number of (especially Czech) scholars point out that the situation may well be more complex than this. They point to various parallel developments within Western European countries, such as the significance of out-of-church movements, anti-clericalism, de-traditionalization, but also the rise of new spiritual outlets (Nešpor 2004). Nevertheless, the number of people who publicly declare to profess a faith, let alone ecclesiastic forms of Christianity, has been constantly decreasing. According to the last census (2011), some 2.17 million out of ca. 10.5 million people living in the Czech Republic claimed to be believers (www.scitani.cz/ sldb2011/eng/redakce.nsf/i/home).

Since the early 1900 s there has been a permanent Pentecostal/charismatic presence in the area of what is the present-day Czech Republic. Yet, the numbers of Pentecostal/charismatic Christians have always been modest. During the Nazi occupation, Pentecostal/charismatic forms of Christianity were prohibited in the region. During most period of the Communist regime, Pentecostal/ charismatic Christians were forced to join other established Christian churches. Only in the late 1980s, the government officially acknowledged the existence of the Czech branch of the Assemblies of God (www.scitani.cz/ sldb2011/eng/redakce.nsf/i/home; Bubík 2005).

Today, Pentecostal/charismatic Christians represent a small proportion of the aforementioned number of the people who claim to be believers with ca. 18 thousand members in nine officially registered churches. Yet it must be stated that almost all Pentecostal/charismatic churches have been constantly growing throughout the last over twenty years, unlike most of other Christian denominations in the Czech Republic. Nevertheless, their influence on the Czech society, including the Christian oikumene, still remains marginal.

\section{2 (Nigerian) Immigration to the Czech Republic}

According to the Czech Statistical Office, in 2011 there were some 436 thousand foreigners living in the Czech Republic (www.czso.cz/csu/cizinci.nsf/ kapitola/ciz_pocet_cizincu). However, a vast majority of them come from other Central and East European countries, especially Ukraine, Slovakia, Russia and Poland. There are not significant numbers of immigrants from Africa or Asia (with the exception of the Vietnamese minority). This situation has various reasons. The Czech Republic never had any colonies. In addition, it is a country without access to the sea. Moreover, the forty years of the Communist regime 
had isolated the country to a large extent. Finally, even today it is not a country of choice for most immigrants, unlike some economically more thriving countries of Western and Northern Europe.

In 2006, the Czech Statistical Office registered 333 Nigerian citizens in the territory of the Czech Republic. Most of these people are college students who come for a limited period of time. Having finished their studies, they either return to Nigeria or move to Western Europe to live there. They come from various tribes and in most cases profess Christianity (Bittnerová, Moravcová et al. 2005: 315).

Three Types of Nigerian-initiated Pentecostal/Charismatic Churches in Prague

Unlike in some other European cities, the number of Nigerian-initiated Pentecostal/charismatic churches in Prague is small. As a matter of fact there is only one other Nigerian-initiated Pentecostal/charismatic congregation in addition to the three explored in this chapter (The Church of Pentecost, founded by the Nigerian pastor Ikena Chukwubuiko). The three churches discussed here represent different ways of interaction between Nigerian Pentecostalism and the local Czech society.

\subsection{Mountain of Fire and Miracles}

The Czech branch of the Mountain of Fire and Miracles Ministries (MFMCzech: Hora ohně a zázraků) was established by Pastor Yomi Akinyemi in 2009 which makes it the first branch of the larger MFM in a post-socialist country (http://www.mountainoffire.wz.cz/). In the past, Pastor Akinyemi used to live in Prague (in what used to be former Czechoslovakia) as a student; he studied at the University of Economics in Prague between 1979 and 1985, taking his degree (M Eng.) in international trade. Having left civil service in Nigeria upon his own request, he returned to the Czech Republic together with his wife Yinka (also Nigerian) and three children in 2007 to start a ministry in Prague. Indeed, the Prague MFM was formally founded on the first Sunday (4 January) of 2009. As Akinyemi says, his long-term experience with the Czech society has helped him understand the context better; this, in turn, enables him to address some issues and challenges peculiar to the Czech people more effectively in his ministry and to be more relevant when proclaiming the gospel. To Akinyemi's mind, examples of such issues are a high divorce rate, depression, drug abuse, and prostitution. He says: 
Even though the message of the gospel is the same for the Czech Republic and Nigeria, there are different problems in different places that Christian ministry and mission need to tackle. Examples of such problems are poverty in Nigeria, suicides and murder in the USA, and depression, psychiatric problems and divorces in the Czech Republic (Interview with Yomi Akinyemi, 16 April 2012, Prague).

Although the Prague MFM keeps close contacts with both the headquarters in Nigeria and other MFM churches, especially in Europe, its main objective is to serve the Czech people through its prayer and deliverance ministry. As Pastor Akinyemi emphasizes, the Prague MFM does not seek to be an African church; quite the contrary, it first and foremost reaches out to Czechs, while not forgetting other people either. By 'other people' Akinyemi refers predominantly to immigrants of African origin. In addition to Czechs and Nigerians, its members come from Angola, Ghana, Uganda, Guinea-Bissau, Poland etc. Unlike other Nigerian-initiated Pentecostal and charismatic churches around the globe, however, the Prague MFM can with its up to thirty regular members (among which the pastor, his wife and their three children) be by no means regarded as a mega-church, the tendency which is not likely to change in the near future. Of those thirty members, about a half is of the Czech origin, the fact which makes the Prague MFM an interestingly multicultural and, for the Czech conditions, rather unusual Christian congregation.

The relatively small membership, however, does not seem to bother either the pastor or the MFM-members. They view their mission as a faithful presence in the Czech environment with steadfast prayers for God's blessing, healing and deliverance of the Czech society. 'The Czech Republic is a second home,' says Pastor Akinyemi and adds that he often prays for his new home-country.

'Being there' for the Czech people also translates into the way the Prague MFM pursues its ministry. According to Akinyemi, the church tries to de-emphasize the features of Nigerian (or, generally, African) culture as much as possible since he believes that the diversity in cultural expression can lead to disunity in the proclamation of the gospel. Avoiding the use of any local African languages, Czech and English only is spoken during the church events. Interestingly enough, even when only African worshippers are attending a certain event, Czech songs will still be included and, furthermore, the sermon (preached in English by Pastor Akinyemi or his wife) will also be translated into Czech (again, by the pastor himself or his children who speak excellent Czech). In addition, it is worth mentioning that the Prague MFM writes its own hymns, both in Czech and English. Therefore, the Prague MFM can in no way be regarded as a platform for Nigerian immigrants to foster their cultural and/or ethnic identity. 
Nevertheless, in spite of all the efforts to be as embedded in the Czech context as possible, the elements of Nigerian culture and Pentecostal/charismatic expressions of faith still come into play. For example, some African musical instruments are used to accompany the singing during the worship. Also, hymns are sung with vibrant bodily expression, while standing, clapping and moving one's body in the rhythm of the music, the matter rather atypical for Czech mainline churches. In addition, and more importantly, certain theological accents of the Prague MFM show signs of African Pentecostalism. In particular, it concerns a phenomenon which Kwabena Asamoah-Gyadu observes in the context of the God Embassy in Ukraine and the Kingsway International Christian Center (KICC) in London. He describes it as 'the ardent belief in the existence of territorial demons' (Asamaoh-Gyadu 2012: 31) within African Pentecostal/charismatic circles which finds an expression in so-called Jesus Marches (also known as Marches for Life). The latter are symbolic re-enactments of the biblical Jericho March, recorded in Joshua 6. These Marches, Asamoah-Gyadu argues, 'amounting to enchanted "noises", that is screaming, shouting, stamping of feet and clapping of hands, have been reinvented in churches like God Embassy and KICC as ways of fighting enemies and taking control of spaces illegally occupied by the "enemy"' (Asamoah-Gyadu 2012: 31). Even though the Jesus Marches/Marches for Life are not part of the Prague MFM ministry, the belief in demons and evil spirits which can 'illegally occupy' various spaces and the need for spiritual warfare are numbered among the most important emphases of the church. Therefore, as Pastor Akinyemi states, he was very sad to discover that Christians in the European, post-Enlightenment milieu do not admit the existence and power of demons and witchcraft. Part of his mission here in Europe, then, is to make the Europeans aware that there are different types of witchcraft in different contexts, which are, nevertheless, still mighty and harmful, and to help them fight these witchcrafts in the name of Jesus. He puts it quite illustratively:

In my ministry here [in the Czech Republic] I have been trying to teach people that there are various kinds of black magic and witchcraft all around. However, God gives us a way to fight them through the power of prayer. So, I try to teach the members of my church how to pray when they sit on the bus next to a person with tattoos and piercing, when they have bad dreams or when they are trying on some clothes in a C\&A [clothing store].

Thus the MFM contributes to the overall picture of Christianity in the Czech context with the emphasis on the reality of demonic powers. The latter are 
believed to have an impact on human life even in ordinary everyday situations, such as through people 'with tattoos and piercing' or when trying on pieces of clothing which might have been 'infected' by the touch of an evil wizard. However, Pastor Akinyemi admits that it is very difficult to talk to Czech people, including Christians in his church, about the issues related to supernatural powers. Still, he does not seem to be discouraged by these difficulties; for him, it is important to be in Prague and pray for the Czech society. The M FM ministry of prayer and deliverance thus has a certain 'vicarious significance' - the members of the church pray for people at large to deliver them from evil powers.

\subsection{Covenant Parish Prague (The Redeemed Christian Church of God)}

The Redeemed Christian Church of God (RCCG) is one of the most widelyestablished Nigerian-initiated Pentecostal/charismatic churches in Central and Eastern Europe, with churches in Russia, Poland, Romania, Belarus or Hungary. Covenant Parish Prague (CPP), the Czech branch of the RCCG was started in April 2006 by Pastor Innocent Eddo, who moved to Romania in December 2006 to missionize there (www.rccgprague.cz). Since then, the CPP has been 'under the leadership of the Holy Spirit with Pastor Augustine Otekhile as the undershepherd' (www.rccgprague.cz/story.php).

Pastor Augustine Otekhile came to the Czech Republic with his family in 2006 and has lived there ever since. In addition to serving as a pastor to the congregation, Otekhile, like Pastor Akinyemi of the Prague MFM, also studied at a Czech university. He majored in natural resources and environment and took his graduate degree (M Eng.) from the Czech University of Life Sciences in Prague in 2008. His residence and experience enabled Pastor Otekhile, to his mind, to get to know the Czech context well. He enumerates the challenges the proclamation of the gospel faces in the Czech society:

Well, there are quite many challenges. First of all, coldness of the [Czech] people must be mentioned. They are quite low in responsiveness and they do not like organizations of any kind. Then there is also a challenge of language and culture. Understanding the context makes one deliver the message better. For example, I have noticed that the Czechs do not like noise as we do in Africa, but they like to drink beer and eat pork. ${ }^{3}$

3 This is an interesting remark given the fact that Pastor Otekhile is not a convert from Islam. He comes from a Christian background but, as he puts it, 'in the real context of Christianity (i.e. a total surrender of my life to the Lordship of Jesus Christ), I became a devoted Christian effective April 1992.' 
It is part of their culture. Therefore, I do not mind these things (e-mail communication with Augustine Otekhile, 5 August 2013; Interview with Augustine Otekhile, 15 May 2012, Prague).

Pastor Otekhile nevertheless admits that most of his sermons are on salvation and right living and the level of contextualization does not need to be very high. Yet, there is an awareness that one needs to 'get into the environment' before trying to proclaim the gospel. That was one of the reasons why the members of the CPP decided to conduct a self-learning Czech course. Pastor Otekhile comments this decision as follows: 'English unites, but Czech opens to the environment, to the people.' Being a congregation of ca. $75^{-80}$ members, mostly students and working people, coming from various backgrounds-Nigeria, Botswana, Zambia, Namibia, Ghana, Ukraine, and the Czech Republic-English has become the language of communication for the members of the CPP. And yet, holding strong to their missionary vision, they also realize the need to study Czech in order to reach out to the Czech people. As Pastor Otekhile says, Nigerian elements are intentionally discouraged to maintain cordial relationships between members of different cultural backgrounds within the congregation. In spite of the fact that the language policies of the two churches are quite different, this would, in theory, make the CPP very similar to the Prague MFM.

However, the reality is rather more complex. As the visitor is coming to the CP P place of worship, he or she makes note of African music coming out of the speakers. There are no worship songs in Czech; a vast majority of hymns is in English, interspersed with some songs in African languages. The music - of a very good quality, one must say—is performed vividly. The sermon is preached in English; no translation into Czech is provided. In the prayers at the end of the worship there are included prayers for Africa, Nigeria, but also for the Czech Republic. The way these prayers are phrased is very intriguing. With regard to Nigeria, the members of the congregation ask God to protect southern [sic!] Nigeria and to weaken the power of its enemies as well as to destroy every weapon that would like to destroy the peace and prosperity of Nigeria. With regard to the Czech Republic, the members pray to the Lord to manifest His power in the Czech Republic and to the Czech atheists so that they may come to know Him.

The demographic composition of the CPP is most interesting as well. A vast majority of the congregation is black with whites being almost exclusively the wives or girlfriends of the African members. Furthermore, it is interesting to note that a substantial number of African female members-not males-are wearing their traditional African clothes to church. The picture the visitor to 
the CPP worship gets is the one of a predominantly black African congregation consisting of younger people who cherish their African/Nigerian identity, while strive to integrate into their 'second home', i.e. the Czech Republic. While it cannot be asserted that the CPP would intentionally try to create a cultural-religious ghetto, its case seems to support the thesis mentioned in the beginning of this paper in its claim that Nigerian Pentecostalism does not seem to attract the indigenous white and non-Pentecostal/charismatic population of Europe.

\subsection{Holy Ghost End Time Ministries Intl. (the Oasis Church)}

Afe Adogame suggests that there are at least two main 'genres' of Africaninitiated churches around the world: those operating as branches of mother churches with headquarters in Africa, and those started by African immigrants in migration contexts as brand new churches, often developing an active missionary outreach back to Africa and elsewhere (Adogame 2008:310). Holy Ghost End Time Ministries Intl. (HG ETMI) represents the second genre. Founded by Pastor Festus Nsoha of Nigeria in 1993, HGETMI is based in Prague and from there it is involved in missionary endeavors to many parts of the world, including Africa and the USA. Pastor Nsoha became Christian in 1985 and after his conversion spent five years of missionary work in Cameroon before moving to former Czechoslovakia in 1993. Unlike Pastors Akinyemi and Otekhile, Nsoha did not come as a student, but for religious purposes only.

According to its mission statement published on the HGETMI official website (trilingual: English, Czech and Russian), the organization pursues 'preaching the full message of the Good News, bringing healing and restoration, establishing churches and Christian groups' (www.holyghost.cz). In addition to its main Oasis Church ('Církev Oáza' in Czech) in Prague, ${ }^{4}$ Hgetm I have founded churches and home church groups in other five towns of the Czech Republic so far (www.holyghost.cz/About-HGETMI.html).

In comparison with the other two churches discussed above, HGETMI seems to be best established in the Czech context in terms of membership and contextualization. First of all, it has over 100 active members. It is very interesting to note that Pastor Nsoha, his wife and three children are the only Nigerian or, for that matter, African members of the congregation. Otherwise, the Oasis Church mainly consists of the people of the Czech, Russian and Ukrainian origin. In addition, there are many members coming from the

4 The congregation used to meet in the premises of a hotel near the center of Prague. Recently, it bought its own premises in the village of Nebušice, a few kilometers from Prague. As of the end of July 2013, all programs and meetings of the church take place there. 
Roma ethnic background. The languages used in the congregation are Czech, English and Russian; when one of those languages is used for sermons, prayers, announcements etc., translation into the other two is always provided. Czech, Russian and Roma members are also intensively involved in leading the services (hosting, prayers, announcements, songs etc.) and various other activities of the church, with Pastor Nsoha being responsible mainly for preaching and lecturing.

In addition, the aspects of Nigerian Pentecostalism of the Oasis Church are least visible if compared to the Prague MFM or the Covenant Parish Prague. As a matter of fact, it is virtually absent. No African songs are featured during the worship; the hymns sung by the congregation are either in English, Czech or Russian. The same is true for the use of African musical instruments; the accompanying music style and instruments resemble usual contemporary services known from (especially) Evangelical and Pentecostal churches around Europe and North America. Interestingly enough, there are no Black African members in the ensemble 'Gospel Singers' which is in charge of the music during worship services.

Also, sermons of Pastor Nsoha do not betray any particular features of Nigerian Pentecostalism. This could be possibly explained by a relatively long time Nsoha spent pastoring and preaching outside his African context. However it must be stated that his sermons are not specifically contextual either. Pastor Nsoha emphasizes that the gospel is universal, 'the same for everyone', no matter whether it is proclaimed in the Czech Republic or Nigeria or the UsA. And indeed, if not for an African pastor, one would barely notice that one is worshipping with a Nigerian-initiated congregation. As a matter of fact, in its theology and expression the Oasis Church resembles American Pentecostal/ charismatic communities more than Nigerian or even Czech ones. A possible explanation points to the fact that HGETMI was initiated by a Nigerian in the Czech context and not initiated in Nigeria by a Nigerian. Since HG ETMI is not a daughter congregation of a famous Nigerian church, like RCCG or M FM, it is not necessarily a primary place of worship and spiritual life for African immigrants to Prague. This leaves more space for Czech and other European members to exercise influence on the formation and activity of HGETMI. Nevertheless, the shaping power of Pastor Nsoha is decisive. Being formed by his close contacts with the us context, Festus Nsoha moulds the 'face' of the church accordingly. For instance, the HGETMI (Oasis Church) worship service is thus characterized by its centeredness around a simple message with several practical steps to be implemented in the believers' life, an informal style of speech seasoned with jokes and anecdotes, the employment of up-to-date gadgetry, and contemporary popular music. 
We have seen that the three churches under research represent different examples of Nigerian-initiated and -led Pentecostal/charismatic ministry in the local Czech context. It has also become clear that these churches employ various, both converging and diverging strategies to pursue their mission. I will now discuss some aspects of these strategies, including contextual knowledge/ experience of the pastor, language politics, worldview, worship style, and outreach policy. Such analysis will help us realize the complexity of the approaches Nigerian-initiated Pentecostal/charismatic churches take in order to move in their ministry beyond their ethnic and cultural origin. First, all of the pastors in the case-study churches show considerable knowledge of and experience with the local Czech context. While Pastor Nsoha of HGETMI has the advantage of having spent the longest time in the Czech Republic (since 1993), Pastor Akinyemi of the Prague MFM and Pastor Otekhile of the CPP can benefit from their studies at Czech universities, the experience which exposed them to the local Czech environment. Unlike Otekhile and Nsoha who came to the Czech Republic after it had been established as an independent country, Yomi Akinyemi experienced living not only in the former Czechoslovakia (on January 1, 1993 Czechoslowakia ceased to exist; from it emerged two countries: the Czech Republic and Slowakia), but also within the political reality of Communism, which came to an end in November 1989 with the Velvet Revolution. This experience, I believe, gives him even better understanding of the Czech context. Moreover, Akinyemi speaks the best Czech out of the three pastors.

Second, all three churches realize the importance of language in their ministry. While they all discourage the use of African languages in their worship as well as other church and missionary activities, their respective language policies otherwise differ significantly. Both the Prague MFM and HGETMI put a great emphasis on addressing people in the vernacular. In their language policy, the Prague MFM is very serious about their mission statement of having a ministry, first and foremost, to the Czech people. The aforementioned interpretation strategy at worship services and Bible studies, provided by Pastor Akinyemi, his wife or one of their children, is a case in point. And it apparently bears fruit as there are a modest, yet stable number of Czech (and non-Englishspeaking) members of the congregation.

Similarly, HGETMI also consistently pursues a policy of interpretation. However, it adds another language, Russian, to English and Czech as many church members come from countries of the former Soviet Union. In contrast to the Prague MFM, HGETM I employs the service of skilled interpreters and the 
use of modern technologies (overhead projectors, interpreting devices etc.). Moreover, small group meetings ('home churches') are held in the language of the majority of its members (either Czech or Russian), whereas translation to the other languages, including English, is available. Again, such a strategy obviously proves to be successful as the majority of the church members comes from either Czech- or Russian-speaking background.

The CPP with its actual language politics represents a contrast to the other two churches. The CPP in theory acknowledges the need to master the Czech language in order to reach out to the indigenous population more effectively. Therefore, many members of the church study Czech in a language course. However, one tends to question the effectiveness of this language course as it is self-organized and self-taught by the members of the CPP. Moreover, one also wonders about the actual intention to put Czech into practice in the life of the church since all of the CPP's events and ministries as well as public presentations (the website, published leaflets etc.) are in English only. Even though it seems that there is no need for using Czech as the church members from the Czech (and other European) background are well versed in English, one cannot help thinking that the CPP would be more effective in its publicly proclaimed cross-cultural ministry in the Czech context if it addressed the local population in the vernacular.

Third, the worldview of the respective churches plays a significant role in their ministries. The leadership of all three churches recognizes the importance of understanding the context as well as possible. For example, Pastor Akinyemi of the Prague MFM identifies depression, psychiatric problems and a high divorce rate as problems typical of the Czech situation. And yet, the churches do not actively seek to produce contextual theologies relevant to their ministries. Quite the contrary, it is claimed that the gospel message is the same for all the people and should be preached accordingly; this statement, needless to say, is in tension with the aforementioned observation on the importance of contextual identification and understanding. As a result, sermons, addresses and prayers, be they by the pastors or other members of the churches, are quite uniform with a focus on salvation and right living of an individual. Individual vices, such as smoking, drinking, gambling or inappropriate sexual behavior, are often criticized, while the social and structural dimensions of sin are virtually neglected. This fact brings the case-study churches very near to many Czech Pentecostal/charismatic or Evangelical churches. This proximity is even more evident in case of HGETMI due to vivid contacts and cooperation of Pastor Nsoha with American churches.

Despite the identified struggle for de-Africanization, the churches are not completely free of the African worldview. This is especially true for the Prague 
MFM with their belief in the existence of territorial demons and witchcraft. As we have seen, this worldview often clashes with the worldview of even Prague MFM members of Czech origin, not to mention the Czech population at large. Nevertheless, this fact does not seem to bother the Prague MFM leadership much as this congregation understands its mission primarily as a prayer and deliverance ministry for the sake of the Czech people in general, thus assuming a certain kind of vicarious priestly presence in the society.

Fourth, the worship styles of all three case-study churches bear both resemblances and unique traits. The resemblances include a high degree of involvement of church members in organizing and facilitating worship services, vibrant and energetic music, or a strong emphasis on prayer and adoration. However, there are also elements peculiar to the respective churches. For example, the CPP conducts its services in English only, including sermons and hymns. This fact, along with the reality of employing some hymns in African languages, not only sets the CPP apart from the Prague MFM and HGETMI, both of which use Czech (and, in case of HGETMI, even Russian) in their worship, but also diminishes the CPP's ability to reach out to the Czech population.

While the Prague MFM seeks to have a consistently bilingual, Czech and English worship services, its style betrays the biggest degree of African traits. These are apparent especially in music which makes abundant use of traditional African instruments. Yet, it seems that such a style is appreciated by the Czech church-goers, not least due to the fact that they are able to understand everything what is going on and participate actively at the worship service.

Unlike the two aforementioned churches which make use of several preachers and every member is in principle welcome to deliver a sermon, Pastor Nsoha is the main and most influential preacher for the HG EтM I Oasis Church. While such a practice encourages authoritarian leadership as well as certain uniformity, it also gives the members certainty in what they can expect. The observation of the congregation indicates that such a style is appreciated.

And finally, all three churches make use of various outreach strategies. The Prague MFM is involved in street evangelism, helping homeless people and visiting patients in hospitals. The church has also been active in prison ministry and now considers reaching out to immigrants living in Czech immigrant camps. In addition, the church members invite their friends to worship services, Bible studies, and prayer meetings. The church occasionally cooperates with some Czech churches of Pentecostal/charismatic orientation when organizing some evangelistic or prayer events. All these examples indicate a good potential for crossing the cultural and ethnic boundaries and engaging in effective ministry. A possible hindrance is represented by the fact that there are few members on the 'mission team'. 
The CPP makes use of three particular outreach methods. The first two include the Internet and brochures and flyers distributed in shops or on streets. According to Pastor Otekhile, however, the third method, involving one-on-one encounter, is the most effective by far. Since the CP P believes that such evangelism on individual basis is preferable to large-scale events, such as crusades or stadium evangelizations, it hardly ever engages in cooperation with other churches or missionary organizations, including Czech ones. This might possibly lead to their isolation and a 'cultural ghetto'. Another potential hindrance to their ministry is language, as very few CPP members speak Czech at an adequate level.

In its outreach, HGETMI focuses on different groups of people, including the youth, children and women. The church is also actively involved in ministry abroad. The examples include Pastor Nsoha's 'preaching tours' in the USA and mission trips to Ukraine and Poland. The church music group Gospel Singers represents another missionary tool as it seeks 'to use music and worship as an instrument of blessings, salvation, healing and deliverance for all who listen to it' not only in the course of worship services, but also at conferences and concerts in different halls and in the open air (http:// www.cirkevoaza.cz/). To a much larger degree than the Prague MFM and CPP, HGETMI cooperates with Czech and international churches and missionary organizations in missionary events on different occasions. These include conferences and stadium-, tent-, street-, or open air evangelizations. HGETMI also makes use of technology in order to reach out to people. For example, its Sunday worship services are broadcasted live via Oaza $T V$, a channel operated by HGETMI. In addition, a video archive is available on the HGETMI website, containing materials from various camps and conferences (www.holyghost.cz/Video-Archive.html). It is obvious that HGETMI is interested in cross-cultural ministry in the Czech Republic and beyond. Such a varied outreach policy can help the church become an active missionary force in the Czech context in the future.

\section{Conclusion}

Unlike some Western or even Eastern European countries, there are no Nigerianinitiated Pentecostal/charismatic mega-churches in the Czech Republic. This is largely due to historical reasons, including the Czech Republic being a country with no colonial history and no access to the sea and the isolation during the Communist regime. Even though it is difficult to estimate exact numbers of Nigerian immigrants to the Czech Republic, all of them 
came to the country as individuals, mostly students; there were no major immigration waves.

In addition, Pentecostal/charismatic forms of Christianity have never taken really deep roots within the Czech society. Even though there has been over a hundred year history of Pentecostal/charismatic presence in the Czech Republic (or its predecessors), its influence-even within the Christian circles-must be deemed as marginal.

The phenomenon of Nigerian-initiated Pentecostal/charismatic churches in the Czech Republic needs to be considered with these actualities in mind. The present chapter has explored three of such churches, based in Prague, in pursuit of an answer to the question, how and to what extent are these churches able to cross ethnic and cultural barriers in their ministry in the local Czech environment? The three churches were interpreted as three models of various answers to this question. In the ministry of the Oasis Church (HGETMI) the Nigerian Pentecostal/charismatic element is least prominent and visible as the church shows more European and American features. The fact that it does not have any ties with a mother church in Nigeria, being a church originally founded in the diaspora, might play a role in this development. In addition, the status of the pastor and the role of his personal development are also of major importance in this respect.

The Prague MFM makes much effort to discourage possibly all (religious and cultural) Nigerian and, generally, African elements since it perceives its raison d'être in being a church with the primary focus on the Czechs. Yet, some of its emphases show typically African Pentecostal/charismatic provenience. Most notably, it is the preoccupation with the spiritual warfare against demonic powers (witchcraft) as the Prague MFM seeks to become a ministry of prayer and deliverance, with a certain kind of a vicarious presence in the Czech society for the sake of its people. This observation indicates, inter alia, that the factor of numerical growth is not to be viewed as the only sign of success of Nigerian-initiated churches in migration contexts.

The Covenant Parish Prague (RCCG) gives an impression of a Black African church for Black African people, despite the painstaking effort of the leadership as well as members to be as open to the society at large as possible. There might be various reasons for this situation. General disinterest or ignorance of the Czech majority society could come into the picture. On the other hand, the idea of having their 'own' church might represent an attractive platform for immigrants living in a completely foreign environment to foster their religious as well as cultural and/or national identity. After all, there are examples of other 'national churches' in the Czech environment whose members, while 
being better integrated in the Czech society than Nigerians, still tend to view 'their' churches in the same manner.

The mere fact that the three analyzed Nigerian-initiated churches in the Czech Republic do not statistically show large numbers of members coming from a European background is not enough to claim that they would not represent an active missionary force. This chapter has introduced and analyzed different strategies these churches use to move beyond their ethnic and cultural origin. It has suggested that a complexity of factors needs to be taken into consideration when exploring a missionary potential of Nigerianinitiated churches (and, indeed, any churches in migration contexts). For these particular cases, the chapter has shown that there is both a positive (active missionary force) and a negative (cultural ghetto) missionary potential. It will be exciting to observe, what the ministry of these churches will look like in the future.

\section{Bibliography}

Adeboye, Olufunke (2007). "'Arrowhead' of Nigerian Pentecostalism: The Redeemed Christian Church of God, 1952-2005." Pneuma: The Journal of the Society for Pentecostal Studies 29, 1: 24-58.

Adogame, Afe (2008). "Up, Up Jesus! Down, Down Satan! African Religiosity in the Former Soviet Bloc - the Embassy of the Blessed Kingdom of God for All Nations." Exchange 37, 3: 310-336.

Asamoah-Gyadu, J. Kwabena (2005). "An African Pentecostal on Mission in Eastern Europe: The Church of the "Embassy of God" in the Ukraine." Pneuma: The Journal of the Society for Pentecostal Studies 27, 2: 297-321.

Asamoah-Gyadu, J. Kwabena (2006). "African Initiated Christianity in Eastern Europe: Church of the 'Embassy of God' in Ukraine." International Bulletin of Missionary Research 30, 2: 73-75.

Asamoah-Gyadu, J. Kwabena (2012). “To the Ends of the Earth': Mission, Migration and the Impact of African-led Pentecostal Churches in the European Diaspora." Mission Studies 29, 1: 23-44.

Bittnerová, Dana and Mirjam Moravcová (2005). Kdo jsem a kam patř́m? Prague: Sofis.

Bubík, Rudolf (2005). Historie letničního hnutí, 6 volumes, Albrechtice: Nakladatelství Křestanský život.

Hunt, Steven (2000). "Belief and Value-Orientation of the 'New' Nigerian Churches." Modern Believing 41, 4: 16-22. 
Hunt, Steven (2002). "'A Church for All Nations': The Redeemed Christian Church of God." Pneuma: The Journal of the Society for Pentecostal Studies 24, 2: 185-204.

Nešpor, Zdeněk R. (2004). "Religious Processes in Contemporary Czech Society." Sociologický časopis / Czech Sociological Review 40, 3: 277-295.

Olupona, Jacob K. (2003). "Globalization and African Immigrant Religious Communities." In Jennifer I. M. Reid, ed. Religion and Global Culture. Lanham MD: Lexington Books: 83-96.

Währisch-Oblau, Claudia (2009). The Missionary Self-Perception of Pentecostal/ Charismatic Church Leaders from the Global South in Europe: Bringing Back the Gospel. Leiden: Brill.

Walker, Geoffrey (2011). “Faith without Church.” Unpublished paper presented at a conference of the Charles University and the International Students Trust, Prague 11-16 April 2011.

Wilkinson, John (1986). "Black Christianity in Britain. Survival or Liberation: A White Perspective and Testimony." International Review of Mission 75, 297: 25-33.

Working Group on Mission and Ecclesiology of the Commission for World Mission and Evangelism (2012). "The Church as Mission in its Very Life: Towards Common Mission to Christ and Visible Unity." International Review of Mission 101, 1:105-131.

www.czso.cz/ (accessed 15 June 2016)

www.glopent.net (accessed 24 August 2013)

www.holyghost.cz/ (accessed 5 August 2013)

www.holyghost.cz/Gospel-SingersEN35.html (accessed 23 August 2013)

www.holyghost.cz/Video-Archive.html (accessed 23 August 2013)

www.mountainoffire.wz.cz/ (accessed 15 June 2016)

www.rccgprague.cz (accessed 5 August 2013)

www.rccgprague.cz/story.php (accessed 5 August 2013)

www.scitani.cz/sldb2011/eng/redakce.nsf/i/home (accessed 5 August 2013) 